\title{
Legal Protection Bonda And Bulango Languange: In Reality And Prospect
}

\author{
Novendri M. Nggilu, SH.,MH ${ }^{1}$ \\ Lisnawaty W. Badu ${ }^{2}$ \\ Suwitno Y. Imran ${ }^{3}$
}

\begin{abstract}
1Faculty of Law, Universitas Negeri Gorontalo, Indonesia. E-mail: novendrilawfaculty@ung.ac.id
2 Faculty of Law, Universitas Negeri Gorontalo, Indonesia. E-mail: lisnawaty69@ung.ac.id

${ }^{3}$ Faculty of Law, Universitas Negeri Gorontalo, Indonesia. E-mail: suwitnoimran@gmail.com
\end{abstract}

\section{Article Info}

\section{Keywords:}

Protection;

Preservation;

Constitutional Promise.

How to Cite (APA Citation Style):

Nggilu, N.M., Badu, L.W., Imran, S.Y. (2021). "Legal Protection Bonda And Bulango Language: In Reality And Prospect". Jambura Law, JALREV 3 (1): 19-36

(C) 2021 - Nggilu, M.N.

Under the license CC BY-SA 4.0

\begin{abstract}
In 2017 Indonesia has a special law governing the promotion of culture as if it were an oasis in the midst of the "extinction" of protection against extinct regional languages including bonda and bulango. This research is intended to examine the policy prospects that the Government of Bone Bolango needs to take in protecting and maintaining the language of Bonda and Bulango as a form of fulfillment of Article 32 paragraph (2) of the 1945 Constitution promising leerplicht. The scientific methods used in this study are a type of normative research with a legal approach, approach case, and conceptual approach. The results showed that the protection reality of Bonda and Bulango language is far from the maximum word, it is seen from the lack of documentation about bulango morphology and the condition of the use of Bulango language which leaves only one speaker, while Bonda even bonda dictionary but its use is still limited to Suwawa people only, with the condition of the speakers reduced. The prospects of policies that can be done by the local government in protecting and preserving the Language of Bonda and Bulango include the establishment of local regulations on the protection and preservation of Bonda and Bulango as the basis for bone bolango regency government which will regulate the obligations of educational institutions both formal and informal primary and secondary level in the protection and preservation of Bulango and Bonda languages, the obligations of the village government, the obligations of the people, and the role of the indigenous council or duango lo lipu, including the source of the budget for the protection and preservation of the Bonda and Bulango languages, and followed by the technical policies of others as a tangible form of preservation of the two languages.
\end{abstract}




\section{Introduction}

The minority languages and regional languages issue in the world faces a serious problem that is the threat from extinction. ${ }^{4}$ Nettle and Romaine ${ }^{5}$ for example predicts that there are $90 \%$ of the world's languages now considered endangered. Even Krauss have predicted from the trend of the number of 6000 world languages currently in use, between $20 \%-50 \%$ will "die" at the end of the twenty-first century. ${ }^{6}$ If it breaksdown into Indonesian conditions, referring to the data released by the Ministry of Education and Culture from 1991 to 2017 has been mapped and verified in languages, and the number is 652 Regional Languages. ${ }^{7}$ Of the 652 Regional Languages recorded and identified, only 71 regional languages mapped vitality or survival, resulting in 19 regional languages being endangered and 11 regional languages categorized as extinct, 4 critical languages, two languages experiencing setbacks, 16 languages in a vulnerable condition, and 19 languages in safe status. ${ }^{8}$

The birth of Law Number 5 of 2017 concerning the Advancement of Culture such as an oasis in the middle of a barren desert, how not, Indonesia which is a country that is rich in the value of its local wisdom and constitutionally, is recognized and guaranteed by the Republic of Indonesia Constitution in its journey since independence until 2016, it did not have specific legal instruments regulating the protection and preservation of the cultural heritage of the ancestors in the regions.

Gorontalo province as one of the areas that is included in one of the indigenous areas based on mapping conducted by Van Vollen Hoven. ${ }^{9}$, where there are 19 indigenous territories and Gorontalo one of which is included in the shared area of Bolaang

\footnotetext{
4 S May. (2000). "Uncommon Languages: The Challenges and Possibilities of Minority Language Rights". Journal of Multilingual and Multicultural Development, Vol. 21, No. 5: 366.

5 Nettle and Romaine. "The Extinction of the world's languages" Quoted in Innocent Maja. "Towards the Protection of Minority Languages in Africa". LLM Program (Human Rights and Democratisation in Africa) of the University of Pretoria. p. 1

${ }^{6}$ M Krauss. "The world's languages in crisis". Quoted in Innocent Maja, ibid.

7 Indonesian Ministry of Education and Culture. "Badan Bahasa Petakan 652 Bahasa Daerah di Indonesia", retrieved from https://www.kemdikbud.go.id/main/blog/2018/07/badan-bahasa-petakan-652-bahasadaerah-di-indonesia. Accesed Friday, October 5, 2018 at 22.27 Wita.

8 Republika. (edisi 21 Feb 2018). “ 19 Bahasa Daerah terancam punah",retrieved from https://www.republika.co.id/berita/nasional/umum/18/02/21/p4hio8384-19-bahasa-daerah-

terancam-punah. Accessed February 15, 2019 at 15.41 Wita.

${ }_{9}^{9}$ Supriyanto, et.al,. (2012). "Islam and Local Wisdom, Religious Expression in Southeast Asia. Yogyakarta: Deepublish. p. 134
} 
Mongondow, hence certainly has a wealth of local wisdom and culture must be protected and preserved. Gorontalo as a region that is very thick with culture and local wisdom, has a traditional philosophical value known as "adati hulo-hulo'o to syara'a, syara'a hulo-hulo'o to Kitabullah",10 this philosophy value means that custom bearing syara ', syara' be sensible to kitabullah, meaning that all aspects of people's lives in Gorontalo, including their government, must be based on religious values, especially Islam, which in the majority is the religion most widely adhered to by the people of Gorontalo. Therefore, it is not surprising that Gorontalo Province is known for its slogan as the "Serambi Madina" area. In terms of regional literature, Gorontalo has 4 regional languages, namely Hulondhalo or Gorontalo Language which are mostly used by Gorontalo people, then there are also Bonda, Bulango Language, and Atinggola Language.

In addition to Gorontalo Province which is heavily socio-cultural with the value of local wisdom, it must be admitted that regions which administratively enter the Gorontalo Province region have distinctive cultural properties and show the characteristics of the existing regions. One of them is Bone Bolango District. The area that is designated as tauwa lo lipu or the origin of Gorontalo society is historically and socio-culturally known to have Khasa Bone Bolango Language namely Bonda (Suwawa) and Bulango (Tapa) Language. The cultural richness of this language aspect is unfortunately faced with alarming conditions, especially Bulango Language. The languages of Bonda and Bulango which are the oldest Languages in Gorontalo Province have started to be abandoned by the people, if the users of Bonda Language still range in $20 \%$ of the people in Bone Bolango, this condition is very different from the Bulango Language which uses only about $2 \%^{11}$, even active speakers from the Bulango language there is only one person left, and even then it enters the elderly phase.

The condition of Bone Bolango Regency as a Tauwa lo Lipu area, with the existing conditions worrying because of the potential for extinction, it should be necessary for

\footnotetext{
10 See, Bakung, D.A, (2019). "Tertium Comparatum Pengaturan Hak Ulayat Masyarakat Adat Dalam Pelaksanaan Akad Nikah", Jurnal Legalitas, Vol. 12 (1): 48-56., Ismail, D.E., Nggilu, N.M., \& Tome, A.H. (2019) "The Urgency of Gorontalo Traditional Cultural Regulation Expression as a Form of Legal Protection for National Culture" ICIDS, 1-5

11 Survey results conducted by the Chairperson of the Culture and Education Office of Bone Bolango District in 2018.
} 
a role for the regional government as an entity that holds the rights to the richness of traditional cultural expressions, especially regional languages, need to formulate a legal policy whose orientation is to protect and preserve both languages. If all this time the local government has put in place the protection and preservation of Bonda (Suwawa) and Bulango Language (Tapa) on aspects of self-awareness of the community, then there needs to be a paradigm transformation and the perception that the worrying situation about the extinction of cultural expressions needs to be responded quickly, wisely and persuasive based on social values, namely the value of Mohuyula (togetherness).

\section{Problem Statement}

Based on the description of the above background, the authors formulated a problem that would be answered and elaborated in this paper, while the formulation of the problem was the prospect of what legal policies should be taken by the government of Bone Bolango Regency to protect and preserve the Bonda and Bulango Languages of Bone Bolango Regency.

\section{Method}

The type of research used in this study is a type of normative legal research, with a statutory approach, case approach and conseptual approach. The Statute approach is intended to describe the juridical anatomy of the regulation of regional languages in the Indonesian Law, while the case approach is to describe the condition of regional languages which are national cultural assets that begin to experience critical extinction conditions including the Bonda and Bulango languages of Bone Bolango Regency, Gorontalo Province, while the choice Conseptual approach is intended to describe the prospects for the policy needed by the Government of Bone Bolango Regency in an effort to protect and preserve the Bonda and Bulnago languages. The legal material used in this study is primary legal material that has authoritative or binding strength (Constitution and Law), as well as secondary legal material which is legal material that supports the description and explanation of primary legal materials and objects of studies conducted such as books, journals, newspapers and so on. While the technique of data collection is done by library studies and interviews with related parties both Head of Culture and Education Division of Bone Bolango District, speakers, to the Bone 
Bolango Society. The results of the data obtained are then processed with technical prescriptive analysis.

\section{Analysis or Results}

\subsection{Juridical Anatomy of Regulations For The Protection and Preservation of Regional Languanges in Indonesia n Law}

Soekarno once stated Jas Merah, never forget history, because history can be a compass that can lead us to the right conditions. As explained earlier, that culture in the historical trajectory has recorded that this nation was born from an awareness to liberate itself from colonial rule, this condition then triggered the unity of the whole community which consisted of many regions and tribes that existed. The success in seizing independence was then expressed by the formulation of Pancasila as a philosophy extracted from the daily lives of the Indonesian people who had lived before independence. ${ }^{12}$

If tracing the souls of the Indonesian independence struggle, especially the mystical situation of discussion in the Preparatory Business Entity of Indonesian Independence and also the Preparatory Committee for Indonesian Independence, it will be found that the establishment of an independent Indonesian state is based on the awareness to unite various regions in Aceh, Borneo, Malaya, Celebes, Irian Jaya, East Timor into one country by relying on the principle of Bhineka Tungga Ika. ${ }^{13}$ As a logical consequence of Bhineka Tungga Ika, the appreciation and respect for regional specialties is very important.

At the July 17, 1945 session, the Preparatory Committee for Indonesian Independence in particular the education and teaching sub-committee ${ }^{14}$ succeeded in formulating outlines of education and teaching to be submitted to Gunseikan Kakka on July 18, 1945 , one of which emphasized that education and culture are based on religion and

\footnotetext{
12 Noor Ms Bakri. (2014). “Pendidikan Kewarganegaraan”. Yogyakarta: Pustaka Pelajar. p. 27

13 See the Indonesian Constitutional Court. (2010). "Naskah Komprehensif Perubahan Undang-Undang Dasar Negara Republik Indonesia Tahun 1945, Latar Belakang, Proses, dan Hasil Pembahasan 1999-2002 Buku II SendiSendi Fundamental Negara". Jakarta: Secretariat General and Registrar's Office of the Constitutional Court. p. 90 14 The sub-committee of the PPKI Education and Teaching was chaired by Ki Hajar Dewantara, and members including Husein Jayadininggrat, Asikin, Roosseno, Ki Bagus Hadikusumo, and KH. Mas Mansur. See the Indonesian Constitutional Court. (2010). "Naskah Komprehensif Perubahan Undang-Undang Dasar Negara Republik Indonesia Tahun 1945, Latar Belakang, Proses, dan Hasil Pembahasan 1999-2002 Buku II Sendi-Sendi Fundamental Negara". Jakarta: Secretariat General and Registrar's Office of the Constitutional Court. p. 18.
} 
culture the nation and towards the direction of the safety and happiness of society. The national culture in question is an old and original culture which is found as cultural peaks in regions throughout Indonesia as counted as the nation's culture. ${ }^{15}$ Even specifically about regional languages get their own place in the Outlines of Education and Teaching especially Article III point 2 which emphasizes the synergy of teaching about Indonesian Language with Regional Languages where it is stated that; in areas that have their own language, which are well maintained by the people, are required to teach the language of unity starting in grade 3 in the first school, with the guarantee that there will be enough intelligence for children in Indonesian, if they study in public schools. ${ }^{16}$

Although in the discussion and debate in BPUPKI (Investigating Committee for Preparatory Work for Indonesian) Indonesian Independence Preparation) and PPKI (Preparatory Committee for Indonesian Independence) the aspects of regional language as part of the assets of national culture received attention, the results of the 1945 Constitution did not place regional languages in specific articles or verses, because in Chapter XV the Flags and Languages have 2 (two) articles only regulate the language of the country, namely Bahasa. Although it does not provide confirmation of regional languages in special arrangements in the 1945 Constitution, but when looking at the original intent of the establishment of the 1945 Constitution at the BPUPKI and PPKI meetings reflected efforts to respect regional languages are reflected in Article 32 which emphasizes the government advancing Indonesian national culture. The meaning of national culture is the pinnacles of regional culture throughout Indonesia. ${ }^{17}$

In the regime of the adoption of the Constitution of the Republic of Indonesia (RIS Constitution), the placement of respect for regional languages does not get a special portion in the RIS Constitution, because in Part 3 concerning State Symbols and Languages Article 4 only confirms that Indonesian is the official language of the Republic of Indonesia. even if the 1945 Constitution stipulated on August 18, 1945 places culture in a special article which is leerplict in which the government promotes

\footnotetext{
15 Ibid, p. 19

${ }^{16}$ Ibid, p. 21

17 See Indonesian Constitutional Court, Naskah Komprehensif..., loc.cit., p. 19
} 
national culture including culture in the region, in the Constitution the RIS does not get a special portion.

The RIS Constitutional regime which only did not last up to a year was later replaced by the Provisional Law which materially did not place regional language as a cultural richness of the territory of the UUDS (Undang-undang Dasar Sementara or temporary constitution) body. Similar to the 1945 Constitution and the RIS Constitution, the regulation of language is only about the official language of the country, Indonesian.

The reformation of Indonesian Constitutional carried out in 1999-2002 through the amendment to the 1945 Constitution of the Republic of Indonesia, gave rise to discussion and debate about the regulation of culture, especially regarding regional languages which showed phenomena as languages that began to experience extinction. ${ }^{18}$ This can be traced in the atmosphere of discussion and debate during the amendment to the 1945 Constitution of the Republic of Indonesia in the MPR (Majelis Permusyawaratan Rakyat or Indonesian Consultative Assembly). There are at least two opinions related to the regulation of regional languages in the body of the constitution. The first opinion assumes that there is no need for a regulation on regional language in the constitution, that the regulation of regional languages is sufficiently only regulated in the law, ${ }^{19}$ while the second opinion assumes that the placement of norms in the body of the constitution becomes very important because it is related to the personality of the tribe which is also part of the State of Indonesia. ${ }^{20}$ the debate then produced various proposals for article 36 as reflected in the proposal of Happy Bone Zulkarnaen from the Golongan Karya (Golkar) party faction at the 48th Plenary Meeting of the Ad hoc Committee on June 27, 2000 which submitted the proposed substance article 36 paragraph (2) regional languages were part of from Indonesian culture that lives, is respected, and maintained by the state. According to him, in addition to the existence of bahasa as the official language of the country, bahasa also has Regional Language as part of a culture that was born and arose from the efforts of the whole Indonesian

\footnotetext{
18 See the opinion of Dewa Gede Atmadja. Indonesian Constitutional Court. "Naskah Komperehensif ...", op., Cit., p. 428

${ }^{19}$ See the opinion of Soetjipto from the faction of the group delegates. the Indonesian Constitutional Court. "Naskah Komperehensif ...", ibid., p. 144

20 Dewa Gede Atmadja expressed his opinion by proposing the provisions of Article 32 and Article 36 by regulating the culture and language of the region due to their very close personality, so that the regulation of language not only regulates the official language of the country but also respects regional languages which are also assets of the nation's culture. Ibid. p. 427.
} 
mind. ${ }^{21}$ Although the proposal has emerged in relation to the formulation of constitutional norms about regional languages, the thing agreed upon in the discussion of the second and third amendments was the temporary cultural aspects of the regional language the discussion continued in the fourth period of change.

During the fourth amendment of January 10, 2002 Hatta Mustafa from the Regional Representative Faction considered that cultural aspects must be regulated more clearly and in detail, Mustafa argued that if Indonesian culture is a national identity, then it should maintain good old cultural values and respect regional languages as the government's duty as a crystallization of efforts to promote national culture.22 Agreeing with Mustafa, Vincent T. Radja is even harder in proposing the norm formulation of regional languages with the formulation of "the state respects and is obliged to maintain regional languages as national culture", this opinion reflects the affirmation of state duties in terms of maintaining regional languages as constitutional premise of Indonesia. ${ }^{23}$

The dynamics and situations of mystical debate about the importance of regulating the protection and respect of the state of regional languages finally gave birth to the final formula of Article 32 paragraph (2) which affirms that the state respects and maintains regional languages as a national cultural wealth.

The arrangement of regional languages stipulated in Article 32 paragraph (2) of the 1945 Indonesian Constitution is then further regulated in several laws. In other things, Law Number 28 of 2014 concerning amendments to Law Number 19 of 2002 concerning Copyright regulates traditional cultural expressions, in Article 38 it is stated that in connection with the copyright to a creator whose creator is unknown, this law regulates as folows:

1) Copyright on traditional cultural expressions held by the State.

2) The state must inventory and maintain traditional cultural expressions as referred to in paragraph (1).

\footnotetext{
21 Ibid, p. 485.

22 Ibid, p. 497-498

23 Ibid, p. 521
} 
3) The use of traditional cultural expressions as referred to in paragraph (1) must pay attention to the values that live in the carrying peoples.

4) Further provisions regarding Copyright held by State for traditional cultural expressions as referred to in paragraph (1) shall be regulated by Government Regulation.

The purpose of traditional cultural expressions as mentioned in Article 38 includes:

a. Textual verbal, both oral and written, in the form of prose and poetry, in various themes and content of messages, which can be either literary or informative narratives;

b. Music, including vocals, instrumental or combinations;

c. Motion, including dances;

d. Theater, including puppet shows and folk plays;

e. Fine arts, both in two-dimensional and three-dimensional forms made of various materials such as leather, wood, bamboo, metal, stone, ceramics, paper, textiles and others or their combinations; and

f. Traditional ceremonies. ${ }^{24}$

Furthermore, the regulation on the preservation of regional languages is also regulated in Law Number 20 of 2003 concerning the National Education System. As a law that covers the implementation of national education, this law is the crystallization of the state's goal to educate the life of the nation. In Article 33 of this law regional languages can be used as the language of instruction in the education stage if needed in the delivery of certain knowledge and/ or skills.

In addition, in Law Number 24 of 2009 concerning Flags, Languages, National Symbols and National Songs, to containing definitions of regional languages as languages used by generations of Indonesian citizens in areas in the territory of the Republic of Indonesia, ${ }^{25}$ also the use of regional languages in scientific writing and publications in the field of special studies, ${ }^{26}$ the use of regional languages in the delivery of information about domestic or foreign goods or service products circulating in Indonesia, ${ }^{27}$ the use

\footnotetext{
${ }^{24}$ Explanation of Article 38 of Law Number 19 Year 2002 As Amended by Law Number 28 of 2014 concerning Copyright.

25 Article 1 paragraph (6) of Law Number 24 of 2009 concerning Flags, Languages, National Symbols and National Songs

${ }^{26}$ Article 35 of Law Number 24 of 2009 concerning Flags, Languages, National Symbols and National Songs

27 Article 37 of Law Number 24 of 2009 concerning Flags, Languages, National Symbols and National Songs
} 
of regional languages in general signs, pointers public facilities, banners, and other information tools that are public services, ${ }^{28}$ and the use of regional languages in information through mass media. ${ }^{29}$

After a long journey to replenish Indonesia's independence, finally in 2017 the government passed a law specifically about culture. This law is a strategic form of crystallization of provisions in the constitution concerning the promotion of national culture which includes the culture in the region. In this law, culture also covers aspects of regional languages. ${ }^{30}$ One of the objects of cultural advancement is the language that is interpreted in the law as a means of communication between people, both in the form of oral, written, and gestures, including, Indonesian and regional languages.

Protection and preservation of this culture, including language and through inventory, ${ }^{31}$ include recording and documenting, setting and updating data, safeguarding, ${ }^{32}$ maintenance including revitalization, repatriation and restoration, ${ }^{33}$ rescue ${ }^{34}$ publication, ${ }^{35}$ development, ${ }^{36}$ utilization including internalization of cultural values, innovation, improved adaptation facing change, cross-cultural communication, intercultural collaboration. ${ }^{37}$

These arrangements the region was tasked with arranging the main points of the promotion of culture as a document that contained factual conditions, problems and strategic efforts in efforts to carry out protection and preservation as a form of cultural advancement in the region.

\subsection{Reality of The Protection and Preservation Of Bonda and Bolango Languages}

As a country that applies the principles of constitutional democracy, Indonesia certainly in formulating and implementing the 1945 Indonesian Constitution always

\footnotetext{
28 Article 38 of Law Number 24 of 2009 concerning Flags, Languages, National Symbols and National Songs

${ }^{29}$ Article 39 of Act Number 24 of 2009 concerning Flags, Languages, National Symbols and National Songs

${ }^{30}$ Article 5 point h of Law Number 5 of 2017 concerning Promotion of Culture.

31 Article 16 of Law Number 5 of 2017 concerning Advancement of Culture.

32 Article 22 of Law Number 5 of 2017 concerning Advancement of Culture.

33 Article 24 of Law Number 5 Year 2017 concerning Advancement Culture.

34 Article 26 of Law Number 5 of 2017 concerning Advancement of Culture.

35 Article 28 of Law Number 5 of 2017 concerning Advancement of Culture.

${ }^{36}$ Article 30 of Law Number 5 of 2017 concerning Advancement of Culture.

37 Article 33 of Law Number 5 of 2017 concerning Advancement of Culture.
} 
pays attention to the interests of the highest sovereignty holders, which is the peoples. In the context of the formulation of the 1945 Indonesian Constitution, both on August 18,1945 , until the amendment to the 1945 Indonesian Constitution implemented in 1999-2002, the formulation of the 1945 Indonesian Constitution was based on Indonesian constitutional values or refer to constitutional premise. The constitutional premise in the formulation of the 1945 Indonesian Constitution included the Pancasila (Philoshopie Grondslag), the State of Law or the Purpose of Law (Recht idee), custom law (living law), and universal constitutional values such as representation in parliament, restrictions power, including respect for humanity. The constitutional premise discussed and debated both in the drafting of the Constitution on August 18, 1945 until the amendment to the 1945 Indonesian Constitution (1999-2002) was the spirit of the formulation of the article, paragraph in the Indonesian Constitution.

If referring to the Indonesian constitution in this matter is the 1945 Indonesian Constitution, one of the constitutional promises ${ }^{38}$ is an appreciation of the constitutional guarantee that cultural identity and traditional community rights are respected in line with the times and civilizations, ${ }^{39}$ the state is obliged to advance Indonesia's national culture in the midst of civilization the world by guaranteeing people's freedom in maintaining and developing their cultural values ${ }^{40}$ and the state respects and maintains regional language as a national cultural richness. ${ }^{41}$ This constitutional recognition cannot be separated from the awareness of the civilization of a society in the past, even language has a very strong relevance to the character, identity, and identity of a peoples group, or certain tribes and regions. In fact, Aan Setyawan stated that if regional languages shifted, it would not be impossible for a shift in values that existed in society, both a change in outlook on life, and social behavior. ${ }^{42}$

Recognition and preservation of regional languages are actually constitutional promises that must be fulfilled by the state, not only the central government, but also

\footnotetext{
38 Nggilu, N.M, (2019). "Menggagas Sanksi Atas Tindakan Constitution Disobedience terhadap Putusan Mahkamah Konstitusi”, Jurnal Konstitusi, Vol. 16 (1): 43-60

${ }^{39}$ Article 28 point I of 1945 Indonesian Constitution

40 Article 32 paragraph (1) of 1945 Indonesian Constitution

41 Article 32 paragraph (2) of 1945 Indonesian Constitution

42 Aan setyawan, "Bahasa Daerah Dalam Perspektif Kebudayaan Dalam Sosiolinguistik; Peran Dan Pengaruhnya Dalam Pergeseran Dan Pertahanan Bangsa", Diponegoro University, International Seminar "Language Maintenance, July 2 2011, p. 66
} 
the regional government and village government. In constitutional democratic countries the protection of regional languages and even minority languages is one of the serious concerns of the state to be protected..$^{43}$

Sociologically and culturally, Gorontalo Province including Bone Bolango District has different social conditions than other regions such as in Java. If in the Java region, the socio-cultural conditions are very thick, one of which is reflected in the use of regional languages by all people from both the small and the upper classes, both children and the elderly. This condition is slightly different from Gorontalo especially in Bone Bolango, because the use of language will only be found in the community and certain places, the use of everyday language is more intense in using language that is very thick with Manado dialectics. Such conditions, then one of the toughest tests that need to be completed by the government and the people of Gorontalo, especially Bone Bolango who have cultural wealth, namely Bulango Language and Bonda Language is able to protect and preserve the language as a historical inheritance handed down by their ancestors.

Bulango Language as one of the regional languages of Bone Bolango regency is faced with a situation of extinction, this can be seen from the number of Bulango Language users that is not more than 2\%, as well as active speakers who speak Bulango language and literature with only 1 person left and entering old age. The Bulango language, which is the Bone Bolango original language, is ironically the peoples in two villages which administratively are in the South Bolaang Mongondouw regency used more actually. The used of Bulango Language by the peoples in the villages in the South Bolaang Mongondouw regency which is right adjacent to Bone Bolango regency is a community that has a lineage with the people in Tapa or Bulango, the marriage process and domicile is what causes the Bulango language to arrive in the village is in South Bolaang Mongondouw and is used as an everyday language.

During this time, the protection and preservation of the Bonda and Bulango languages still lacked attention, the protection of the regional languages possessed by Bone

\footnotetext{
43 S. Van der Jeught examines the protection of minority languages in Italy. See S. Van der Jeught. (2016). "Protection of Linguistic Minorities in Italy: A Clean with the Past. Journal on Ethnopolitics and Minority Issues in Europe, Vol 15, No. 3: 57
} 
Bolango was only seen by the formulation of the Bonda language dictionary compiled by Mansoer Pateda ${ }^{44}$ and the writings of the Bune Bonda dialect Morphology by Sariati Tome $^{45}$. The work that was born was unfortunately not included in the education curriculum that was required to be taught at the elementary to high school level, even specifically related to the Bulango language there was no trace of the same academic work that specifically described it as the Bulango language dictionary, while social reality showed that the Bulango language was language that faces a critical situation towards the door of extinction.

The extinction condition was only responded to by the Regional Government of Bone Bolango regency by conducting custom seminar which discussed the preservation of traditional cultural expressions including the Bulango language. The custom is a reaction from the birth of Law Number 5 of 2017 concerning the Advancement of Culture which requires the existence of ideas for the promotion of culture, so the implementation of the custom seminar is used as a momentum for the preparation of points of thought for the advancement of the culture of Bone Bolango regency.

\subsection{The Prospect Of Legal Policy Of The Bone Bolango District Government In Protecting and Preserving Bonda and Bulango Languages}

The reaction to the birth of the law that promoted culture which later gave birth to the policy of drafting the ideas of the promotion of culture carried out in 2018 and while running was the right action, but still not complete and comprehensive. If we understand the main points of promoting culture, this document is a general technical document covering all traditional cultural expressions that are owned not only by the people of Bone Bolango regency, but also about traditional cultural expressions held by Gorontalo Province in general even though the scope will more talk about aspects of traditional cultural expressions of Bone Bolango regency. In addition, this document does not have a coercive nature that is reflected if it is regulated in a legal policy that specifically regulates the protection and preservation of its main traditional cultural expressions about the Bulango Language. By the way, in addition to being prepared with basic documents for the promotion of culture, according to the author, it is

\footnotetext{
44 Mansoer Pateda, Yennie P. Pulubuhu. (1985). "Kamus Suwawa-Indonesia". Jakarta: Center for Language Development and Development of the Ministry of Education and Culture.

45 Sariati Tome. (1988). "Morfologi Dialek Bune Bonda". Jakarta: the Ministry of Education and Culture.
} 
necessary to formulate policies that can be taken by the government of Bone Bolango regency to protect and preserve Bulango language and include Bonda (Suwawa). These policies include:

1) Legal policy in the formulation of regional regulations concerning the protection and preservation of Bulango language and Bonda language. This legal policy is very important to be taken, because it can be a strong legal protection for local governments to protect and preserve regional languages. The scope that can be regulated in this regional regulation is the forms of protection and preservation of the Bonda and Bulango languages, the duties and responsibilities of the district government in protecting and preserving Bonda and Bulango languages, the obligations of educational institutions both formal and informal education at the elementary and first levels is the protection and preservation of the Bulango and Bonda languages, the obligations of the village government, the obligations of the community, and the role of the custom council or duango lo lipu, including the source of the budget for the protection and preservation of Bonda and Bulango languages.

2) The normative formulations stipulated in the regional regulations concerning the protection and transmission of Bonda and Bulango Languages are then derived from the policies of the regional government in the protection of the Bonda Language and the Bulango Language, including:

a. Regional governments can collaborate with Universities to prepare studies or research related to Bonda and Bulango language. This research is needed, one of which is to be used in the process of recording the regional language at the Ministry of Education and Culture of the Republic of Indonesia, especially when looking at the existing conditions that Bulango Language is currently used more by people in villages that are administratively located in South Bolaang Mongondouw Regency. This condition certainly raises concerns if the Bulango Language, which is historically the original language of Bone Bolango Regency, will be claimed and recorded by the government of South Bolaang Mongonduw Regency as a wealth of expressions of its traditional culture.

b. The regional government must as soon as possible record the Bonda Language as well as the Bulango Language to the Ministry Education and 
Culture of the Republic of Indonesia. The recording is intended to obtain the legality of ownership of regional languages as a wealth of traditional Bone Bolango expressions and prevent claims of ownership of the Bulango language that is currently potentially occurring.

3) The government policies in the field of preservation of Bonda Language and Bulango Language are carried out in the following ways:

a. Policy in the field of education by incorporating Bonda Language and Bulango Language education into learning materials in primary school education, and junior high school education as the authority of the district government stipulated in Law No. 23 of 2014 concerning Regional Government. This is needed because of our collective awareness that education is not merely an initiative to transfer knowledge and skills, but also involves the transfer of cultural values and social norms, ${ }^{46}$ even if Fuad Hasan's opinion is stated that every effort education means civilization and along with it the history of human civilization has developed. The culture encompasses the entire spectrum, including the language, art, history, and science systems and the values contained in them can be transferred from one generation to another through the educational process. ${ }^{47}$ Therefore, incorporating aspects of culture or incorporating regional language learning including the two Bonda and Bulango languages is important to do in accordance with the level of education and based on material sustainability. In order to support the policy of entering learning Bonda and Bulango Language, the local government can prepare teaching materials that will be taught to students at the level of primary to junior secondary education and in informal education.

b. Policy in the field of state civil apparatus in the Government of Bone Bolango Regency. The policy in question is an obligation to state civilians to use the Regional Language between Bonda or Bulango Language based on an administrative region that has historically been the scope of the Bulango

\footnotetext{
46 See Indonesian Constitutional Court, "Naskah Komprehensif Perubahan Undang-Undang Dasar Negara Republik Indonesia Tahun 1945, Latar Belakang, Proses, dan Hasil Pembahasan 1999-2002", Book IX of Education and Culture, (Jakarta; Secretariat General and Registrar's Office of the Constitutional Court, 2010), p. 7

47 Fuad Hassan. (2004). "Pendidikan adalah Pembudayaan", quoted in Tonni D. Widiastono. "Pendidikan Manusia Indonesia". Jakarta: Kompas dan Yayasan Toyota \& Astra. p. 55
} 
Language area which includes Tapa District and Bone Pantai District, and Bonda Language which covers Suwawa sub-district and so on.

c. Socio-cultural policy. This policy is directed at involving all communities in using the Bonda Language and Bulango Language by means of the determination of Regional Language days, where all communities are obliged to use regional language on a predetermined day based on regional mapping as stated in point $b$.

d. In the recruitment and filling positions of policies both within the local government and filling in village government apparatus. this policy is directed at every person who wants to become a village government apparatus must understand and master the local language based on the location of the assignment. In addition, the regional government can also require every civil servat who wants to hold the position of regional government such as the Sub-District Head, Head of the Health Center, until Echelon 1 Position, through the stages of regional language mastery selection in both Bonda and Bulango Language.

e. The policy of determine the hometown as the center of language preservation. The central determination of regional languages for each language is needed in the future, with the policies adopted by the district government in this case the Regent and Deputy Regent, then each civil servant and prospective village government apparatuses who have not mastered and understood the regional languages can be facilitated through central regional languages formed either in the form of courses or other activities.

\section{Conclusion}

Bonda language (Suwawa) and Bulango language that are at the end of fullness need to get serious attention especially the local government, so as not to be a sin of the accountability of preserving the cultural heritage of the ancestors. Normative formulations (in the form of local regulations) should also be followed by government actions in providing examples and role models for the preservation of Bonda and Bulango language that is at the end of the civility. In addition, there needs to be a policy in terms of requiring the local government to use the language of bonda and bulango 
while requiring it in the job bidding process for the filling of strategic positions in Bone Bolango Regency, even including the recruitment requirements of the village government apparatus is very necessary to be pursued as a form of technical policy of protection and preservation of Bonda and Bulango language, so that it is expected to revitalize and save both languages that become cultural assets of Bone Bolango Regency gorontalo province from the threat of extinction.

\section{References}

Bakri, Noor Ms. (2014). "Pendidikan Kewarganegaraan”. Yogyakarta: Pustaka Pelajar. Bakung, D.A, (2019). “Tertium Comparatum Pengaturan Hak Ulayat Masyarakat Adat Dalam Pelaksanaan Akad Nikah", Jurnal Legalitas, Vol. 12 (1): 48-56.

Hassan, Fuad. (2004). "Pendidikan adalah Pembudayaan", quoted in Tonni D. Widiastono. "Pendidikan Manusia Indonesia". Jakarta: Kompas dan Yayasan Toyota \& Astra.

Indonesian Constitutional Court. (2010). "Naskah Komprehensif Perubahan UndangUndang Dasar Negara Republik Indonesia Tahun 1945, Latar Belakang, Proses, dan Hasil Pembahasan 1999-2002 Buku II Sendi-Sendi Fundamental Negara". Jakarta: Secretariat General and Registrar's Office of the Constitutional Court.

Indonesian Ministry of Education and Culture. "Badan Bahasa Petakan 652 Bahasa Daerah di Indonesia", retrieved from https://www.kemdikbud.go.id/main/blog/2018/07/badan-bahasa-petakan652-bahasa-daerah-di-indonesia. Accesed Friday, October 5, 2018 at 22.27 Wita. Ismail, D.E., Nggilu, N.M., \& Tome, A.H. (2019) “The Urgency of Gorontalo Traditional Cultural Regulation Expression as a Form of Legal Protection for National Culture" ICIDS, 1-5.

May, S. (2000). “Uncommon Languages: The Challenges and Possibilities of Minority Language Rights". Journal of Multilingual and Multicultural Development, Vol. 21, No. 5: 366.

Nettle and Romaine. "The Extinction of the world's languages" Quoted in Innocent Maja. "Towards the Protection of Minority Languages in Africa". LLM Program (Human Rights and Democratisation in Africa) of the University of Pretoria.

Nggilu, N.M, (2019). “Menggagas Sanksi Atas Tindakan Constitution Disobedience terhadap Putusan Mahkamah Konstitusi”, Jurnal Konstitusi, Vol. 16 (1): 43-60 
Pateda, Mansoer Yennie P. Pulubuhu. (1985). "Kamus Suwawa-Indonesia”. Jakarta: Center for Language Development and Development of the Ministry of Education and Culture.

Republika. (edisi 21 Feb 2018). “ 19 Bahasa Daerah terancam punah”,retrieved from https://www.republika.co.id/berita/nasional/umum/18/02/21/p4hio838419-bahasa-daerah-terancam-punah. Accessed February 15, 2019 at 15.41 Wita.

Supriyanto, et.al,. (2012). "Islam and Local Wisdom, Religious Expression in Southeast Asia. Yogyakarta: Deepublish.

Setyawan, Aan. “Bahasa Daerah Dalam Perspektif Kebudayaan Dalam Sosiolinguistik; Peran Dan Pengaruhnya Dalam Pergeseran Dan Pertahanan Bangsa", Diponegoro University, International Seminar “Language Maintenance, July 22011.

Tome, Sariati. (1988). "Morfologi Dialek Bune Bonda". Jakarta: the Ministry of Education and Culture.

Van der Jeught. (2016). "Protection of Linguistic Minorities in Italy: A Clean with the Past. Journal on Ethnopolitics and Minority Issues in Europe, Vol 15, No. 3: 57

\section{Legislation:}

1945 Indonesian Constitution.

Constitution of the Republic of Indonesia of States.

Provisional Constitution.

Law Number 24 of 2009 concerning Flags, Languages, National Symbols and National Songs.

Law Number 19 Year 2002 As Amended by Law Number 28 of 2014 concerning Copyright.

Law Number 5 of 2017 concerning the Advancement of Culture. 